\title{
EFEK KOMBINASI ANTARA MASASE FRIRAGE DAN AKUPRESUR TERHADAP KEKUATAN OTOT EKSTREMITAS ATAS PASIEN PASCA STROKE ISKEMIK
}

\author{
Zaenal Amirudin*, Tri Anonim, Rosmiati Saleh \\ Prodi : Keperawatan Pekalongan Poltekkes Kemenkes Semarang \\ Jl. Perintis Kemerdekaan Pekalongan (0285) 421642, \\ Korespondensi : zaenalamirudin@gmail.com
}

\begin{abstract}
Stroke patients after an attack will leave the main problem of losing voluntary control of motor movements. This will result in muscle weakness in the upper extremities, thus disrupting independence in carrying out daily functional tasks. The aim of the study was generally to examine the effect of a combination of frirage and acupressure massage on the muscle strength of the extremities in post-ischemic stroke patients. This research is quasi experimental with nonequivalent control group design. A total of 22 respondents were recruited by consecutive sampling, consisting of 11 treatment group respondents and 11 control group respondents. Based on the Kolmogorov-Smirnov test, muscle strength data were found to be abnormally distributed, so as to compare muscle strength before and after intervention using the Wilcoxon test in both the intervention group and the control group. Whereas to compare the increase in muscle strength between the treatment group and the control group using the Mann-Whitney test. The results of the study proved that there were significant differences in effectiveness before and after frirage and acupressure massage in the treatment group ( $p$ $<0.05 ; \mathrm{a}=0.002)$. There was a significant difference in the effectiveness of the control group before and after being given acupressure intervention $(p<0.05 ; a=0.002)$. Upper limb muscle strength in the treatment group was greater when compared to the control group with $(\mathrm{p}<0.05, \mathrm{a}=0.05)$.
\end{abstract}

Keywords: Post ischemic stroke, massage frirage, acupressure, upper limb muscle strength

\begin{abstract}
ABSTRAK
Pasien stroke pasca serangan akan meninggalkan masalah utama berupa hilangnya kontrol volunter terhadap pergerakan motorik. Hal tersebut akan berkibat terjadinya kelemahan otot pada ekstremitas atas, sehingga mengganggu kemandirian dalam melaksanakan tugas-tugas fungsional sehari-hari. Tujuan penelitian secara umum untuk menguji efek kombinasi masase frirage dan akupresur terhadap kekuatan otot ekstremitas atas pasien pasca stroke iskemik. Penelitian ini merupakan quasi experimental dengan nonequivalent control group design. Sebanyak 22 responden direkrut dengan cara consecutive sampling, terdiri atas 11 responden kelompok perlakuan dan 11 responden kelompok kontrol. Berdasarkan uji Kolmogorov-Smirnov, didapat data kekuatan otot berdistribusi tidak normal, sehingga untuk membandingkan kekuatan otot sebelum dan setelah intervensi menggunakan uji Wilcoxon pada kelompok intervensi maupun kelompok kontrol. Sedangkan untuk membandingkan peningkaan kekuatan otot antara kelompok perlakuan dan kelompok kontrol menggunakan uji MannWhitney. Hasil penelitian membuktikan terdapat perbedaan efektivitas yang bermakna sebelum dan setelah dilakukan masase frirage dan akupresur pada kelompok perlakuan $(\mathrm{p}<0,05 ; \mathrm{a}=0,002)$. Terdapat perbedaan efektivitas yang bermakna kelompok kontrol sebelum dan setelah diberikan intervensi akupresur $(\mathrm{p}<0,05 ; \mathrm{a}=0,002)$. Kekuatan otot ekstremitas atas pada kelompok perlakuan lebih besar jika dibandingkan dengan kelompok kontrol dengan ( $p<0,05, a=0,05)$.
\end{abstract}

Kata Kunci: Pasca stroke iskemik, Masase frirage, Akupresur, Kekuatan otot ekstremitas atas

\section{PENDAHULUAN}

Pasien stroke pasca serangan akan meninggalkan masalah utama berupa hilangnya kontrol volunter terhadap pergerakan motorik. Hemiplegia atau kelumpuhan satu sisi tubuh merupakan kelainan yang paling sering terjadi akibat adanya lesi pada sisi yang berlawanan dari otak. Hemiparesis atau kelemahan dari satu sisi tubuh, merupakan tanda lainnya yang bisa ditemukan pada pasien stroke. 
Lebih dari 50\% pasien stroke mengalami defisit motorik (Duncan et al, (1992) dalam Adam (2011). Rehabilitasi pada stroke difokuskan pada aspek plastisitas otak, sehingga pemahaman tentang mekanisme pemulihan motorik memiliki implikasi yang penting terhadap rehabilitasi stroke, sebab dapat menyediakan dasar untuk merancang strategi rehabilitasi yang ilmiah pada pasien yang mengalami hemiparesis.

Akupresur dan masase frirage merupakan contoh pengobatan komplementer yang sudah diakui secara medis dan organisasi kesehatan dunia (WHO). Kedua terapi ini apabila dikombinasikan, diharapkan akan mendapatkan hasil yang lebih baik terhadap pemulihan kekuatan otot ekstremitas atas pasien pasca stroke iskemik.

Manusia sehat pada dasarnya memiliki unsur Yin dan Yang yang relatif seimbang, jika salah satu dominan maka kesehatan terganggu atau tidak sehat. Akupresur bertujuan untuk menyeimbangkan Yin dan Yang (Cheung, Li, \& Wong, 2001; Loupatty et al, 1996 dalam Sukanta, 2008). Akupresur adalah teknik pijatan yang menggunakan jari, tangan atau alat bantu seperti kayu yang dilakukan pada titik-titik meridian. Loupatty et al (1996) dalam Sukanta (2008) mengemukakan bahwa pemberian terapi akupresur dengan pemijatan ditujukan untuk mengembalikan keseimbangan yang ada di dalam tubuh, dengan memberikan rangsangan agar aliran energi kehidupan dapat mengalir dengan lancar.

Titik Akupunktur (akupresur) merupakan tempat terpusatnya energi vital (qi) sekaligus merupakan tempat untuk melakukan penekanan sehingga tercapai keseimbangan yin yang dalam tubuh. Terdapat enam titik akupresur di atas regio skapula, yaitu: Large Intestine (LI) 15, Small Intestine (SI) 9, Tripel Energizer (TE) 14, Gallbladder (GB) 21, Small Intestine (SI) 11, Small Intestine (SI) 12 (Alamsyah, 2010).

Masase frirage merupakan gabungan teknik masase atau manipulasi dari friction (gerusan) dan efflurage (gosokan) yang dilakukan secara bersamaan dalam melakukan pijatan. Terapi masase frirage bertujuan untuk pencegahan dan perawatan tubuh supaya tetap bugar dan sehat, selain dari berolahraga dan perawatan medis (Ali Satia Graha dan Bambang Priyonoadi, 2009).

Masase bertujuan untuk merilekskan otot-otot yang tegang, melancarkan peredaran darah, dan limfe. Otot yang tidak rileks akan mengganggu peredaran darah, pembuluh limfe, dan persarafan. Bisa jadi pembuluh darah tertekan atau saraf-saraf terjepit. Akibatnya, peredaran darah menjadi kurang lancar dan saraf menjadi kurang sensitif.

\section{TUJUAN PENELITIAN}

Secara umum tujuan penelitian ini untuk mengetahui pengaruh kombinasi antara masase frirage dan akupesur terhadap kekuatan otot ekstremitas atas pasien pasca stroke iskemik. Sedangkan tujuan khusus, meliputi: 2.1 Mendeskripsikan pengaruh kekuatan otot ekstremitas atas pada kelompok perlakuan sebelum dan sesudah dilakukan intervensi akupresur dan masase frirage, 2.2. Mendekripsikan pengaruh kekuatan otot ekstremitas atas pada kelompok kontrol sebelum dan sesudah dilakukan akupresur, 2.3 Menganalisis perbedaan pengaruh kekuatan otot ekstremitas atas pada kelompok perlakuan yang diberikan intervensi akupresur dan masase frirege dengan kelompok kontrol yang hanya diberikan akupresur. 


\section{RUMUSAN MASALAH}

Kerusakan fungsi motorik menjadi salah satu efek sisa yang paling serius pada pasien stroke. Lebih dari 50\% pasien stroke mengalami defisit motorik (Duncan et al, (1992) dalam Adam (2011). Rehabilitasi pada stroke difokuskan pada aspek plastisitas otak, sehingga pemahaman tentang mekanisme pemulihan motorik memiliki implikasi yang penting terhadap rehabilitasi stroke karena dapat menyediakan dasar untuk merancang strategi rehabilitasi yang ilmiah pada pasien yang mengalami hemiparesis.

Oleh sebab itu perlu penanganan yang memadahi dengan perencanaan yang tepat untuk dapat mengatasi masalah kelemahan otot yang dapat mempengaruhi tugas fungsional sehari-hari. Akupresur dan masase frirage merupakan pengobatan komplementer yang diyakini dapat mencegah dan memulihkan kesehatan, serta sudah diakui oleh organisasi kesehatan dunia (WHO).

Bertolak dari permasalahn tersebut, maka dapat rumusan masalah yang diajukan adalah "Bagaimanakah efek akupresur dan masase frirage terhadap kekuatan otot ekstremitas atas pasien pasca stroke iskemik".

\section{HIPOTESA}

4.1. Terdapat pengaruh kekuatan otot ekstremitas atas pada kelompok perlakuan sebelum dan sesudah dilakukan intervensi akupresur dan masase frirage

4.2. Terdapat pengaruh kekuatan otot ekstremitas atas pada kelompok kontrol sebelum dan sesudah dilakukan akupresur

4.3. Terdapat perbedaan pengaruh kekuatan otot ekstremitas atas pada kelompok perlakuan yang diberikan intervensi akupresur dan masase frirege dengan kelompok kontrol yang hanya diberikan akupresur

\section{TINJAUAN PUSTAKA}

\subsection{Konsep Stroke}

Stroke merupakan gangguan peredaran darah di otak yang mengakibatkan fungsi otak terganggu dan bila berat dapat menyebabkan kematian sebagian sel-sel otak atau infark (Lumbantobing, 2007). Gangguan aliran darah tersebut disebabkan oleh penyumbatan pembuluh darah baik oleh trombus, emboli, stenosis maupun spasme pembuluh darah dan perdarahan akibat pecahnya pembuluh darah.

Stroke dapat dibagi dua karena adanya sumbatan pada arteri yang disebut dengan stroke iskemik dan pecahnya pembuluh darah arteri disebut juga dengan stroke perdarahan. Smith et al, (2001) stroke iskemik terjadi karena adanya obstruksi atau bekuan di satu atau lebih arteri besar pada sirkulasi serebrum. Obstruksi dapat disebabkan oleh bekuan (trombus) yang terbentuk di dalam suatu pembuluh otak atau pembuluh organ distal.

Pada trombus vaskular distal bekuan dapat terlepas, atau mungkin terbentuk di dalam suatu organ seperti jantung, dan kemudian dibawa melalui sistem arteri ke otak sebagai suatu embolus. Terdapat beragam penyebab stroke trombotik dan embolik primer, termasuk aterosklerosis, arteritis, keadaan hiperkoagulasi, dan penyakit jantung struktural. Namun, trombosis yang menjadi penyulit aterosklerosis merupakan penyebab pada sebagian besar kasus stroke trombotik, dan embolus dari pembuluh besar atau jantung merupakan penyebab tersering stroke embolik (Price \& Wilson, 2003). 
Kerusakan fungsi motorik menjadi salah satu efek sisa yang paling serius pada pasien stroke. Lebih dari 50\% pasien stroke mengalami defisit motorik (Duncan et al, 1992). Rehabilitasi pada stroke difokuskan pada aspek plastisitas otak, sehingga pemahaman tentang mekanisme pemulihan motorik memiliki implikasi yang penting terhadap rehabilitasi stroke karena dapat menyediakan dasar untuk merancang strategi rehabilitasi yang ilmiah pada pasien yang mengalami hemiparesis.

\subsection{Konsep Masase Frirage}

Menurut Bambang Priyonoadi dan Ali Satia Graha (2009) menyatakan bahwa masase frirage berasal dari kata: masase yang artinya pijatan, dan frirage yaitu gabungan teknik masase atau manipulasi dari friction (gerusan) dan efflurage (gosokan) yang dilakukan secara bersamaan dalam melakukan pijatan. Terapi Masase Frirage bertujuan untuk pencegahan dan perawatan tubuh supaya tetap bugar dan sehat, selain dari berolahraga dan perawatan medis.

Selain itu, masase merupakan manipulasi yang bertujuan untuk merilekskan otot-otot yang tegang, melancarkan peredaran darah, dan limfe. Otot yang tidak rileks akan mengganggu peredaran darah, pembuluh limfe, dan persarafan. Bisa jadi pembuluh darah tertekan atau saraf-saraf terjepit. Akibatnya, peredaran darah menjadi kurang lancar dan saraf menjadi kurang sensitif.

\subsection{Konsep Akupresur}

Akupresur merupakan salah satu bentuk dari akupuntur dan berusia lebih tua dari akupuntur. Akupresur adalah teknik pemijatan yang dilakukan secara periodik dan terprogram oleh personal yang telah terdidik keterampilannya melalui suatu pelatihan yang kompeten (Santanu, 2008). Jadi akupresur adalah teknik pijatan yang menggunakan jari, tangan atau alat bantu seperti kayu yang dilakukan pada titik-titik meridian.

Menurut Dupler (2005), akupresur merupakan suatu terapi yang efektif baik untuk pencegahan maupun untuk terapi berbagai macam gangguan kesehatan seperti sakit kepala, nyeri, flu, artritis, alergi, asma, gangguan saraf, nyeri haid, masalah sinus, sakit gigi dan lain-lain. Stimulasi titik akupresur juga dapat meningkatkan energi dan perasaan sehat, menurunkan stres, dan meredakan disfungsi seksual. Tidak seperti akupunktur, akupresur mudah dipelajari dan dapat diberikan dengan cepat, biaya murah dan efektif untuk mengatasi berbagai gejala.

Titik Akupunktur (akupresur) merupakan tempat terpusatnya energi vital (qi) sekaligus merupakan tempat untuk melakukan penekanan sehingga tercapai keseimbangan yin yang dalam tubuh. Jalur tersebut merupakan jalur energi secara fisiologis dan mungkin bisa dijelaskan dengan berbagai pendekatan.

Saputra (1996), menjelaskan bahwa titik akupunktur (acupoint) merupakan sel aktif listrik yang mempunyai sifat tahanan listrik rendah dan konduktivitas listrik yang tinggi sehingga titik akupunktur akan lebih cepat menghantarkan listrik dibanding sel- sel lain. Panjalaran dari satu titik akupunktur ke titik akupunktur lainnya melalui jalur meridian (jalur aktif listrik). Titik akupunktur dijelaskan sebagai suatu perforasi silindris yang berbatas tegas dari fascia superfisialis, diameter $2-8 \mathrm{~mm}$ ditutup oleh jaringan ikat dimana lewat bundel neuromuskuler, mempunyai sifat biofisik tahanan listriknya rendah dengan potensial lebih positif (Saputra \& Sudirman, 2009). 
Adanya ujung saraf dan pembuluh darah yang banyak terdapat di sekitar titik akupunktur akan memperbesar respons. Sel mast melepaskan histamin, heparin dan kinin protese yang menyebabkan vasodilatasi. Histamin menyebabkan pelepasan nitric oxide dari endotel vaskuler yang merupakan mediator berbagai reaksi-reaksi kardiovaskuler, neurologis, imun, digestif dan reproduksi. Sel mast juga akan melepaskan platelet activating factor (PAF) yang kemudian diikuti pelepasan serotonin dari platelet. Serotonin merangsang nosiseptor sendiri dan meningkatkan respon nosiseptor terhadap bradikinin. Bradikinin merupakan vasodilator kuat yang menyebabkan peningkatan permeabilitas vaskuler (Saputra \& Sudirman, 2009).

\subsection{Konsep Kekuatan Otot}

Menurut Ginsberg (2008), kekuatan otot secara klinis dapat dinilai dengan mengklasifikasikan kemampuan pasien untuk mengkontraksikan otot volunter melawan gravitasi dan melawanan tahanan pemeriksa. Skala yang sering dipakai adalah Medical Research Council Scale, menggunakan rentang skor 0-5, dimana $0=$ tidak ada kontraksi, 1 = tampak kedutan otot dan sedikit kontraksi, 2 = gerakan aktif yang terbatas oleh gravitasi, 3 = gerakan aktif dapat melawan gravitasi, $4=$ gerakan aktif dapat melawan gravitasi dan tahanan pemeriksa dan $5=$ kekuatan normal.

\section{METODE}

Penelitian ini merupakan penelitian quasi experimental dengan nonequivalent control group design yaitu dua kelompok dengan tes awal dan tes akhir. Sampel diambil secara non probability sampling jenis consecutive sampling, sebanyak 22 responden, terdiri atas 11 responden kelompok perlakuan dan 11 responden kelompok kontrol.

Instrumen untuk menilai kekuatan otot menggunakan skala Medical Research Council (MRC) dengan skala 0-5, yaitu : 0=lumpuh total; tidak ada sedikitpun kontraksi otot; 1=terdapat sedikit kontraksi otot, namun tidak didapatkan gerakan pada persendian yang harus digerakkan oleh otot tersebut; $2=$ didapatkan gerakan, tetapi gerakan ini tidak mampu melawan gaya berat (gravitasi); $3=$ dapat mengadakan gerakan melawan gaya berat (gravitasi); 4=disamping dapat melawan gaya berat (gravitasi), ia dapat pula mengatasi sedikit tahanan yang diberikan; 5 = tidak ada kelumpuhan (normal)

Data penelitian akan dianalisis dengan bantuan program komputer SPSS versi 12 dengan proses sebagai berikut: Editing, Coding, Entry, Cleaning, dan Saving. Analysis Univariat digunakan untuk menganalisis secara deskriptif setiap variabel penelitian dengan membuat tabel frekuensi dan menguji normalitas data. Analisis Bivariat untuk data berdistribusi normal menggunakan uji statistik parametik. Untuk data kekuatan otot tidak berdistribusi normal, sehingga menggunakan uji non parametik atau uji alternarif, Wilcoxon test (Paired t test) untuk membandingkan kekuatan otot sebelum dan setelah perlakuan pada kelompok kontrol dan kelompok perlakuan. Untuk membandingkan kekuatan otot masing-masing setelah perlakuan pada kelompok intervensi dan kontrol menggunakan Mann-Withney U test (uji alternatif untuk Paired t test).

\section{HASIL PENELITIAN}

Variabel yang di uji pada penelitian ini, meliputi kekuatan otot dan rentang gerak ekstremitas atas, baik pada kelompok intervensi maupun kelompok kontrol. Hasil pengukuran disajikan sebagai berikut: 


\subsection{Skore Kekuatan Otot Sebelum dan Setelah Perlakuan}

Tabel 1. Skore Kekuatan Otot Sebelum dan Setelah Intervensi

\begin{tabular}{lllcccc}
\hline Variabel & Kelompok & Pengukuran & Mean & SD & Min & Mak \\
\hline Kekuatan & Perlakuan & Sebelum & 1,64 & 0,50 & 1 & 2 \\
otot & & Setelah & 3,73 & 0,47 & 3 & 4 \\
\cline { 2 - 7 } & \multirow{2}{*}{ Kontrol } & Sebelum & 1,64 & 0,50 & 1 & 2 \\
& & Setelah & 2,91 & 0,53 & 2 & 4 \\
\hline
\end{tabular}

Tabel 1 tampak bahwa adanya perubahan rerata kekuatan otot pada kelompok perlakuan sebelum dan setelah dilakakukan masase frirage dan akupresur. Rerata sebelum dilakukan masase frirage dan akupresur pada kelompok perlakuan sebesar 1,64 dengan standar deviasi sebesar 0,50 dan setelah dilakukan masase frirage dan akupresur sebesar 3,73 dengan standar deviasi 0,47. Pada kelompok kontrol perubahan kekuatan otot sebelum dilakukan perlakuan dengan rerata 1,64 menjadi 2,91 dengan standar deviasi 0,50 menjadi 0,53.

\subsection{Perbedaan Kekuatan Otot}

Tabel 2. Perbedaan Kekuatan Otot Sebelum dan Setelah Masase Frirage dan Akupresur

\begin{tabular}{cclccc}
\hline Variabel & Kelompok & $\begin{array}{l}\text { Sebelum- } \\
\text { Setelah }\end{array}$ & $\mathrm{n}$ & Mean Rank & $\mathrm{p}$ value \\
& & Negatif & 0 & 0,00 & 0,002 \\
\hline Kekuatan otot & Perlakuan & Positif & 11 & 6,00 & \\
& & Sama & 0 & & \\
& & Jumlah & 11 & & 0,002 \\
\cline { 2 - 6 } & Kontrol & Negatif & 0 & 0,00 & \\
& & Positif & 11 & 6,00 & \\
& & Sama & 0 & & \\
& & Jumlah & 11 & & \\
\hline
\end{tabular}

Tabel 2. Tampak bahwa pada kelompok perlakuan sebanyak 11 responden yang mengalami peningkatan kekuatan otot setelah dilakukan masase frirage dan akuprsur. Hal ini berarti terdapat perbedaan yang bermakna sebelum dan setelah dilakukan masase frirage dan akupresur pada kelompok perlakuan $(p<0,05$; $\mathrm{a}=0,002$ ).

Pada kelompok kontrol terjadi perubahan kekuatan otot sebelum dan setelah dilakukan akupresur. Hal ini berarti terdapat perbedaan yang bermakna kelompok kontrol sebelum dan setelah perlakuan $(p<0,05 ; a=0,002)$.

\subsection{Perbandingan}

Tabel 3. Perbandingan Kekuatan Otot Ekstremitas Atas Setelah Masase Frirage dan Akupresur pada Kelompok Intervensi dan Kelompok Kontrol

\begin{tabular}{llrccc}
\hline \multicolumn{1}{c}{ Variabel } & Kelompok & $\mathrm{n}$ & Mean Rank & Selisih & $\mathrm{p}$ value \\
\hline Kekuatan & Intervensi & 11 & 15,27 & 7,74 & 0,002 \\
\cline { 2 - 6 } otot & Kontrol & 11 & 7,73 & & \\
\cline { 2 - 6 } & Total & 22 & & & \\
\hline
\end{tabular}

Tabel 3 Tampak bahwa kekuatan otot ekstremitas atas pada kelompok perlakuan lebih besar jika dibandingkan dengan kelompok kontrol setelah dilakukan masase frirage dan akupresur dengan $(\mathrm{p}<0,05, \mathrm{a}=0,05)$. 


\section{PEMBAHASAN}

Hasil penelitian membuktikan bahwa rerata kekuatan otot ekstremitas atas setelah dilakukan masase frirage dan akupresur berbeda nyata (3,730 dengan kelompok kontrol yang hanya diberikan akupresur saja $(1,64)$. Hasil penelitian ini membuktikan bahwa kombinasi antara masase frirage dan akupresur yang dilakukan secara bersama menghasilkan kekuatan otot yang lebih bermakna dibandingkan pada kelompok kontrol yang hanya dilakukan akupresur saja.

Hasil penelitian terdahulu yang dilakukan oleh Adam (2011), bahwa rerata kekuatan otot yang dilakukan akupresur saja sebesar 2,47. Begitu pula dengan Wayan (2012), bahwa akupresur pada scapula secara bermakna meningkatkan kekuatan otot ekstremitas atas pasien stroke non hemoragik.

Masase frirage merupakan pijatan untuk melakukan perawatan tubuh yang meliputi, friction, effurage, traksi dan reposisi. Sedangkan akupresur merupakan salah satu tehnik pengobatan cina menggunakan penekanan pada titik akupunktur.

Selain itu, masase merupakan manipulasi yang bertujuan untuk merilekskan otototot yang tegang, melancarkan peredaran darah, dan limfe. Otot yang tidak rileks akan mengganggu peredaran darah, pembuluh limfe, dan persarafan. Dengan tambahan akupresur pada titik tertentu sekitar ekstremitas akan mempercepat proses pemulihan bagian yang mengalami kelemahan.

Lebih lanjut Shin \& Lee (2007), bahwa titik akupresur yang berada pada regio skapula memiliki hubungan yang sangat erat dengan titik trigger untuk memperbaiki ekstremitas atas. Titik trigger merupakan titik yang sensitif apabila ditekan akan menimbulkan rangsang pada titik yang jauh dari tempat tersebut. Saputra (1996), menjelaskan bahwa titik akupunktur (acupoint) merupakan sel aktif listrik yang mempunyai sifat tahanan listrik rendah dan konduktivitas listrik yang tinggi sehingga titik akupunktur akan lebih cepat menghantarkan listrik dibanding sel- sel lain. Panjalaran dari satu titik akupunktur ke titik akupunktur lainnya melalui jalur meridian (jalur aktif listrik).

\section{SIMPULAN}

Rerata kekuatan otot pada kelompok perlakuan sebelum dilakukan masase frirage dan akupresur, sebesar 1,64 dan setelah perlakuan sebesar 3,73.

Rerata kekuatan otot pada kelompok kontrol sebelum dilakukan akupresur sebesar 1,64 dan setelah perlakuan sebesar 2,91.

Rerata kekuatan otot ekstremitas atas pada kelompok perlakuan lebih besar jika dibandingkan dengan kelompok kontrol dengan $(\mathrm{p}<0,05, \mathrm{a}=0,05)$.

\section{DAFTAR PUSTAKA}

Adam, M., (2011) Tesis: Pengaruh akrupresur terhadap kekuatan otot dan rentang gerak ekstremitas atas pada pasien stroke pasca rawat inap di RSUP Fatmawati Jakarta, Pasca Sarjana FIK UI.

Alamsyah (2010). Cara lebih mudah menemukan titik terapi acupoint, Petunjuk praktis akupunktur. Jakarta : AsmaNadia Publishing House

Ali Satya Graha dan Bambang Priyonoadi. (2009). Terapi Massage Frirage (Penatalaksanaan Cedera Pada Anggota Tubuh Bagian Atas). Yogyakarta: Fakultas Ilmu Keolahragaan Universitas Negeri Yogyakarta. 
Dupler, Douglas. (2005). Gale Encyclopedia of Alternative Medicine Acupressure http://www.encyclopedia.com/topic/Acupressure.aspx February 15, 2016.

Ginsberg, L. (2008). Lecture notes: Neurologi (Indah R Wardhani, Penerjemah). Jakarta: Penerbit Erlangga

Price, S .A. \& Wilson, L. M. (2002). Pathophysiology: Clinical concept of desease processes. St.Louis: Elsevier Science.

Santanu, Adikara, Tatang. (2008). Pengobatan Akupresur Untuk Kesehatan. Dewan Pengurus ACK Indonesia Edisi ke-3. Jakarta : Sagung Seto

Saputra, K. \& Sudirman, S. (2009). Akupunktur untuk nyeri dengan pendekatan neurosain. Jakarta: CV. Sagung Seto

Shin, B. C. \& Lee, M. S. (2007). Effects of aromatherapy acupressure on hemiplegic shoulder pain and motor power in stroke patients: A pilot study. The Journal Of Alternative And Complementary Medicine,

Smith, N. (2009). Range of motion, exercise. Published by Cinahl Information Systems. http://web.ebscohost.com. Diakses tanggal 18 feb 2016

Sukanta, Putu Oka (2008). Pijat akupresur untuk kesehatan. Depok : Penebar Plus 